\title{
Effect of Pretreatments on the Drying Characteristics and Quality of African Star Apple (Chrysophyllum albidum)
}

\author{
Komolafe, O.M. ${ }^{1}$ \\ Hussein, J. B. ${ }^{2}$ \\ Adebayo, Q. ${ }^{3}$ \\ Abiona, 0.O. ${ }^{4}$ \\ Oke, M.O. ${ }^{5}$
}

.
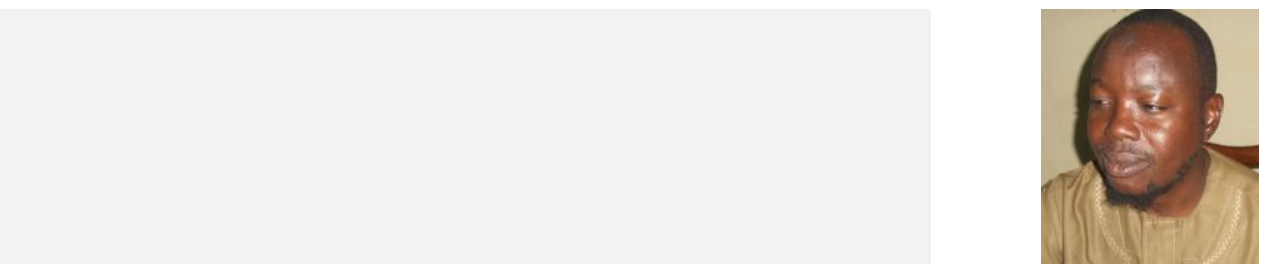

( Corresponding Author)

${ }^{\prime}$ Department of Food Science Technology, Federal Polytechnics, Ilaro, Nigeria.

Email:olakunlekomolafe@gmail.com Tel: +2348037462371

2Department of Food Science and Technology, Modibbo Adama University of Technology, Yola, Adamawa State, Nigeria.

Email:jbhussein01@mautech.edu.ng.Tel:+2348060597615

${ }^{s}$ Department of Food Science and Technology, Federal University Dutsinma, Katsina State, Nigeria.

Email:qadebayo@fudutsinma.edu.ngTel: +2348033585046

${ }^{4}$ Department of Chemical Sciences, Osun State University, Osogbo, Osun State, Nigeria.

Email:oludapobiona@yahoo.com Tel: +2348033523965

${ }^{5}$ Department of Food Science and Engineering, Ladoke Akintola University of Technology, Ogbomoso, Oyo State, Nigeria.

Email:mooke47@lautech.edu.ng.Tel:+2348030758356

\section{Abstract}

Fruits, due to high moisture content, deteriorate quickly when not adequately preserved. Drying, a common preservation method, will affect quality of final product if not properly controlled. Pretreatments prior to drying have been established as a way of retaining product qualities. This study investigated the effect of pretreatments on the qualities of dried African star apple flesh. African star apple fleshes were sliced $(2,4,6$ and $8 \mathrm{~mm})$ and subjected to pretreatments [blanching $\left(80{ }^{\circ} \mathrm{C}\right.$ for $\left.3 \mathrm{~min}\right)$, lime juice $(100 \%)$, ascorbic acid and salt solution $(1: 25 \mathrm{w} / \mathrm{v})$ ]. Untreated samples served as control. Samples were dried in cabinet dryer $\left(50,55\right.$ and $\left.60{ }^{\circ} \mathrm{C}\right)$ at 2 $\mathrm{m} / \mathrm{s}$ constant air flow-rate, monitored at intervals, until constant weight was obtained. Ascorbic acid and colour measurement of the fresh and dried sample were determined using standard method. The moisture contents of the African star apple flesh were observed to reduce from a mean value of $70.44 \%, 71.55 \%$ and $73.24 \%$ to $2.38 \%, 1.91 \%$ and $3.23 \%$ at temperatures of 50,55 and $60{ }^{\circ} \mathrm{C}$, respectively. The total drying time ranged between 7 to $8 \mathrm{~h}$. Colour of the dried African star apple was significantly preserved by the pretreatments used, and low overall color change $(\Delta \mathrm{E})$ was obtained at the lowest drying temperature $(50 \mathrm{oC})$. The ascorbic acid and lime pretreatments however had better colour overall. Lime pretreatment for $2 \mathrm{~mm}$ thick at $50^{\circ} \mathrm{C}$ gave the best result in terms of ascorbic acid retention. Hence, lime juice pre-treatment has potentials of retaining quality of dried fruits.

Keywords: Pretreatments, Drying characteristics, African star apple, Drying qualities.

Citation | Komolafe, O.M.; Hussein, J. B.; Adebayo, Q.; Abiona, O.O.; Oke, M.O. (2019). Effect of Pretreatments on the Drying Characteristics and Quality of African Star Apple (Chrysophyllum albidum). Agriculture and Food Sciences Research, 6(1): 145-154. History:

Received: 21 March 2019

Revised: 30 April 2019

Accepted: 4 June 2019

Published: 15 July 2019

Licensed: This work is licensed under a Creative Commons

Attribution 3.0 License (c) I

Publisher: Asian Online Journal Publishing Group
Contribution/Acknowledgement: All authors contributed to the conception and design of the study.

Funding: This study received no specific financial support.

Competing Interests: The authors declare that they have no conflict of interests.

Transparency: The authors confirm that the manuscript is an honest, accurate, and transparent account of the study was reported; that no vital features of the study have been omitted; and that any discrepancies from the study as planned have been explained.

Ethical: This study follows all ethical practices during writing.

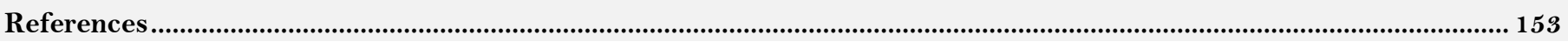




\section{Contribution of this paper to the literature}

This study contributes to existing literature by investigating the effect of pretreatments on the qualities of dried African star apple flesh.

\section{Introduction}

The preservation of fruits and vegetables are essential for extending the shelf life and quality of the product. Preservation technologies include drying, canning, dehydration and others. Among these, drying (dehydration) is especially suited for developing countries with inadequate facilities. It offers a highly effective and practical means of preservation which reduces post-harvest losses and off-set shortages in supply [1]. African star apple (Chrysophyllum albidum) is a forest fruit tree commonly found throughout tropical Africa. It has a fleshy flesh of the fruits which is popularly consumed. The flesh can taste either very sweet or sour. The variation of the fruit colour is said to be correlated with the flesh taste.

The covering of the sweet fruits are seen to be yellow while that of the sour ones are usually a mix of yellow and green colours when mature [2]. It is of great economic value due to its diverse industrial, medicinal and food uses. The fruits are not only consumed fresh but also used to produce jam, jellies, stewed fruit, marmalade, syrup and several types of soft drinks. It is also used for medical purposes due to properties of stalk and fruits. The leaves and seed of some of these fruits and vegetables are used in pharmaceuticals [3].

Pretreatment of fruits prior to drying is highly recommended because it helps to keep light-coloured fruits from enzymatic browning during drying and storage. It also speeds the drying of fruits with tough skins, such as grapes and cherries [4]. Different pretreatment methods have been developed for fruit drying, amongst which are lemon juice, salt solution, honey dip, ascorbic acid, sulfuring, osmotic pre-treatment and blanching [5]. The objectives of this study were to investigate the effects of pretreatments on the qualities (colour and ascorbic acid contents) of dried African star apple flesh.

\section{Materials and Methods}

\subsection{Experimental Procedure}

The African star apples were sorted to remove over-ripe and damaged ones. The fruits were thoroughly washed and peeled before cutting into slices for drying. The flesh of the fruits was cut, using a simple improvised grater, into thin slices of $2,4,6$ and $8 \mathrm{~mm}$ thicknesses. The average initial moisture content of the tropical almonds was determined using AOAC [6] methods as $71.74 \%$, wet basis.

\subsection{Pretreatment of the Samples}

The samples were pre-treated according to the methods of Tunde-Akintunde [7] and Doymaz [8]. The Completely Randomized Design (CRD) was used for the drying experiments with the four pretreatments and one control replicated three times to ensure the consistency of the results. The pretreatments used on the fruit samples were on a weight per volume basis with 1 part of the solute in 25 parts of distilled water (1:25 w/v for 10 min) except for hot water blanching where no solute was added to the distilled water. The pretreatments were coded as shown below:

- CON: No pre-treatment solution.

- BLA: blanched in water bath $\left(80{ }^{\circ} \mathrm{C}\right.$ for $\left.3 \mathrm{~min}\right)$, removed and cooled immediately by placing in a large quantity of tap water for another 3 min to remove excess heat. It is drained in a metal sieve and the excess water blotted off before further processing.

- ASC: 1 part of ascorbic acid in 25 parts of distilled water (1:25 w/v for $10 \mathrm{~min})$.

- LIM: 1 part of lime juice in 25 parts of distilled water (1:25 w/v for $10 \mathrm{~min})$.

- SAL: 1 part of salt in 25 parts of distilled water (1:25 w/v for $10 \mathrm{~min})$.

\subsection{Drying Procedures}

For the drying experiments, $0.2 \mathrm{~kg}$ of fresh pretreated and untreated African star apple fleshes was spared on a single layer inside a perforated tray and dried at temperatures of $50{ }^{\circ} \mathrm{C}, 55{ }^{\circ} \mathrm{C}$ and $60{ }^{\circ} \mathrm{C}$ respectively. The drying was accomplished using an air-convective cabinet dryer of Rhong Machinery Manufacturing Limited series cabinet dryer (model RCD-5) designed to dry food materials under controlled conditions. The temperature of the air in the drying chamber was controllable to suit the drying temperature desired. The air velocity in the drying chamber was controlled by a fan speed controller (adjustable air valve at air inlet and exhaust) constant at $2 \mathrm{~m} / \mathrm{s}$ flow-rate. Also, there was a time controller to monitor drying time. The moisture loss of the flesh during drying was measured at 5 minutes intervals for the first hour, 10 minutes for second hour and at 15 minutes intervals thereafter during the drying process. This was measured using a Gallenkamp electronic balance (model MP 10001 ), which has $0-1,000 \mathrm{~g}$ measurement range with a reading sensitivity of $\pm 0.01 \mathrm{~g}$. The drying processes were stopped when the weight loss became negligible. The experiments were replicated three times and the average results were recorded. After drying, samples were packed and sealed in black polythene to prevent exposure to light and stored until further analyses.

\subsection{Determination of Ascorbic Acid}

Ascorbic acid was determined using the AOAC [6] method. An aliquot (10 g) of the sample was diluted to a fixed volume $(100 \mathrm{ml})$ with $3 \% \mathrm{HPO}_{3}$ and then titrated with 2 , 6-dichlorophenolindophenol. A standard ascorbic acid solution of $5 \mathrm{~mL}$ was added to $5 \mathrm{~mL}$ of $3 \% \mathrm{HPO}_{3}$ and titrated with dye solution to a pink colour, which persisted for $15 \mathrm{~s}$. Ascorbic acid ( $\mathrm{mg} / 100 \mathrm{~g})$ of reconstituted juice was calculated using the formula:

$$
\text { Ascorbic acid }(\mathrm{mg} / 100 \mathrm{ml})=\frac{T \times D F \times V_{1}}{V_{2} \times V_{3}}
$$

where, $T=$ titre; $D F=$ Dye factor; $V_{1}=$ volume made up $(100 \mathrm{ml}) ; V_{2}=$ aliquot of extract taken for estimation $(10$ $\mathrm{g})$ and $V_{3}=$ volume of sample taken for estimation $(10 \mathrm{ml})$. 


\subsection{Colour Measurements}

The fresh and dried fruit colour was determined by direct reading using a colorimeter (MINOLTA model CR200; Minolta Camera Co., Ltd., Osaka, Japan) to obtain the colour values: L* (brightness/darkness), a* (redness/greenness) and b* (yellowness/blueness) as described by Ashebir, et al. [9]. The instrument was calibrated using standard white and black plates before each color measurement. The measurements were taken from randomly selected fresh fruits at three different parts (around halfway from the blossom end) of a fruit and the mean of three readings at these random locations on the sample was used. It should be noted that these same fruit parts were dried and subject to colour measurement after drying.

The fresh African star apple was taken as the ideal sample. The total colour change $(\Delta \mathrm{E})$ parameter is calculated as follows:

where;

$$
\Delta E=\left[\left(L^{*}-L^{* *}\right)^{2}+\left(a^{*}-a^{* *}\right)^{2}+\left(b^{*}-b^{* *}\right)^{2}\right]^{0.5}
$$

$\Delta \mathrm{E}=$ indicates the total colour change of a sample in comparison to colour values of an ideal sample having colour values of $\mathrm{L}^{*}, \mathrm{a}^{*}$ and $\mathrm{b}^{*}$.

$\mathrm{L}^{*}=$ the lightness of fresh samples; $\mathrm{L}^{* *}=$ the lightness of dried samples

$\mathrm{a}^{*}=$ the redness of fresh samples; $\mathrm{a}^{* *}=$ the redness of dried samples

$\mathrm{b}^{*}=$ the yellowness of fresh samples and $\mathrm{b}^{* *}=$ the yellowness of dried samples.

\subsection{Statistical Analysis}

All experiments were performed in triplicate, and the results were expressed as means \pm standard error (SE). Analysis of variance (ANOVA) was carried out to determine any significant differences in measurements using the SPSS statistical software (SPSS 20.0 for Windows; SPSS Inc., Chicago, IL, USA) and considering the confidence level of $95 \%$. The significance of the difference between the means was determined using the Duncan Multiple range test, and the differences were considered to be significant at $\mathrm{p}<0.05$.

\section{Results and Discussion}

\subsection{Drying Characteristics}

The drying experiments gave different values for the moisture contents of the African star apple fruits at different temperatures and thicknesses. Figures $1-3$ show the drying curves for drying the flesh of African star apple of 2, 4, 6 and $8 \mathrm{~mm}$ thicknesses at temperatures of 50, 55 and $60{ }^{\circ} \mathrm{C}$. For drying carried out at $50{ }^{\circ} \mathrm{C}$, the equilibrium moisture content was attained in $8 \mathrm{~h}$. Also, for drying carried out at $55^{\circ} \mathrm{C}$, the equilibrium moisture content was also attained in $8 \mathrm{~h}$. On the other hand, for drying carried out at $60{ }^{\circ} \mathrm{C}$, the equilibrium moisture content was attained in $7 \mathrm{~h}$. The moisture contents of the African star apple flesh were observed to reduce from a mean value of $70.44 \%, 71.55 \%$ and $73.24 \%$ to $2.38 \%, 1.91 \%$ and $3.23 \%$ for temperatures of 50,55 and $60{ }^{\circ} \mathrm{C}$, respectively. In this drying operation, a relative reduction in moisture content with increase in drying time was observed. This also resulted in the drying curve obtained showing a downward curve.
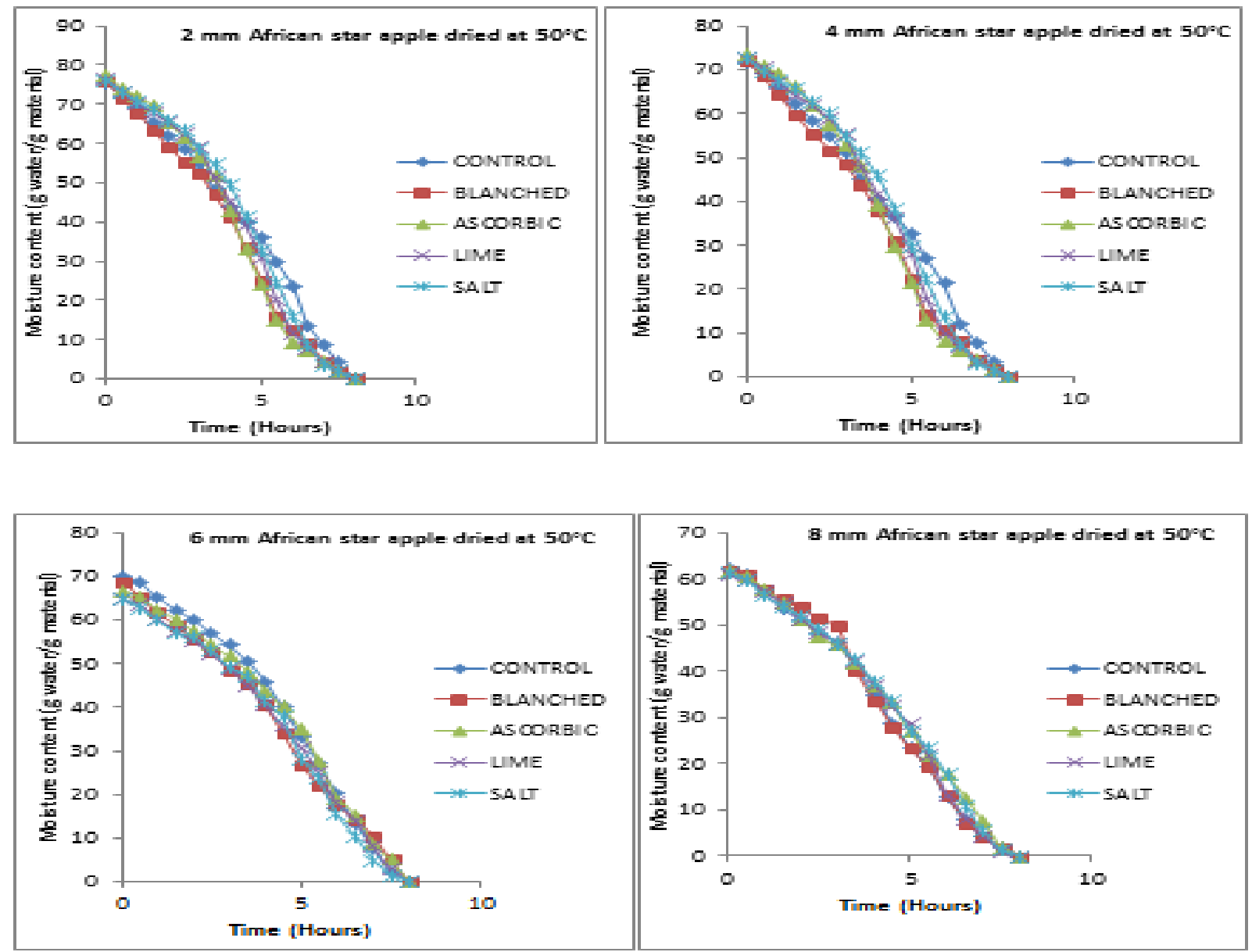

Figure-1. Drying Curves for African Star Apple Flesh of $2 \mathrm{~mm}, 4 \mathrm{~mm}, 6 \mathrm{~mm}$ and $8 \mathrm{~mm}$ Thicknesses Dried at $50{ }^{\circ} \mathrm{C}$. Source: Authors' Findings. 

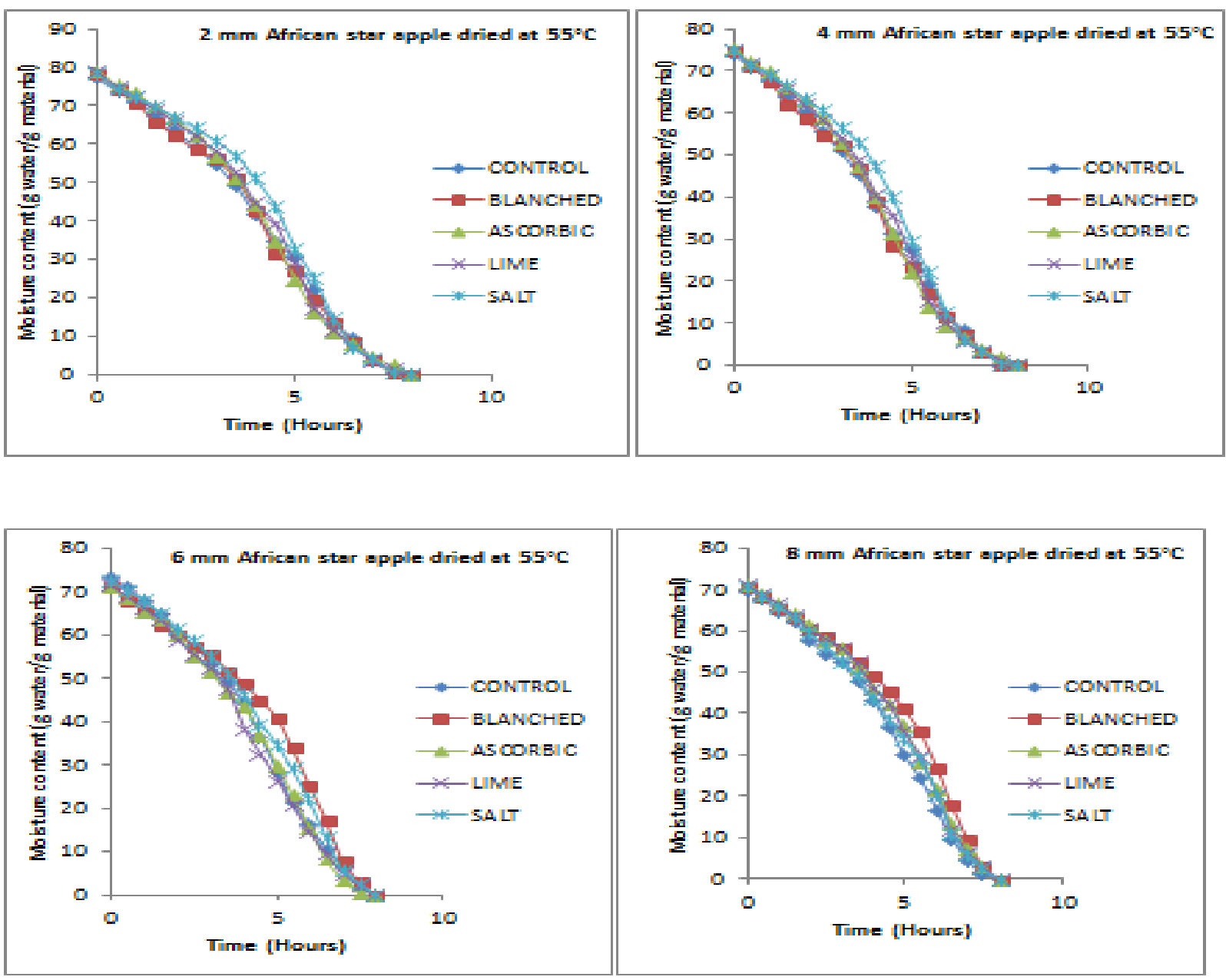

Figure-2. Drying Curves for African Star Apple Flesh of $2 \mathrm{~mm}, 4 \mathrm{~mm}, 6 \mathrm{~mm}$ and $8 \mathrm{~mm}$ Thicknesses Dried at $55^{\circ} \mathrm{C}$. Source: Authors' Findings.
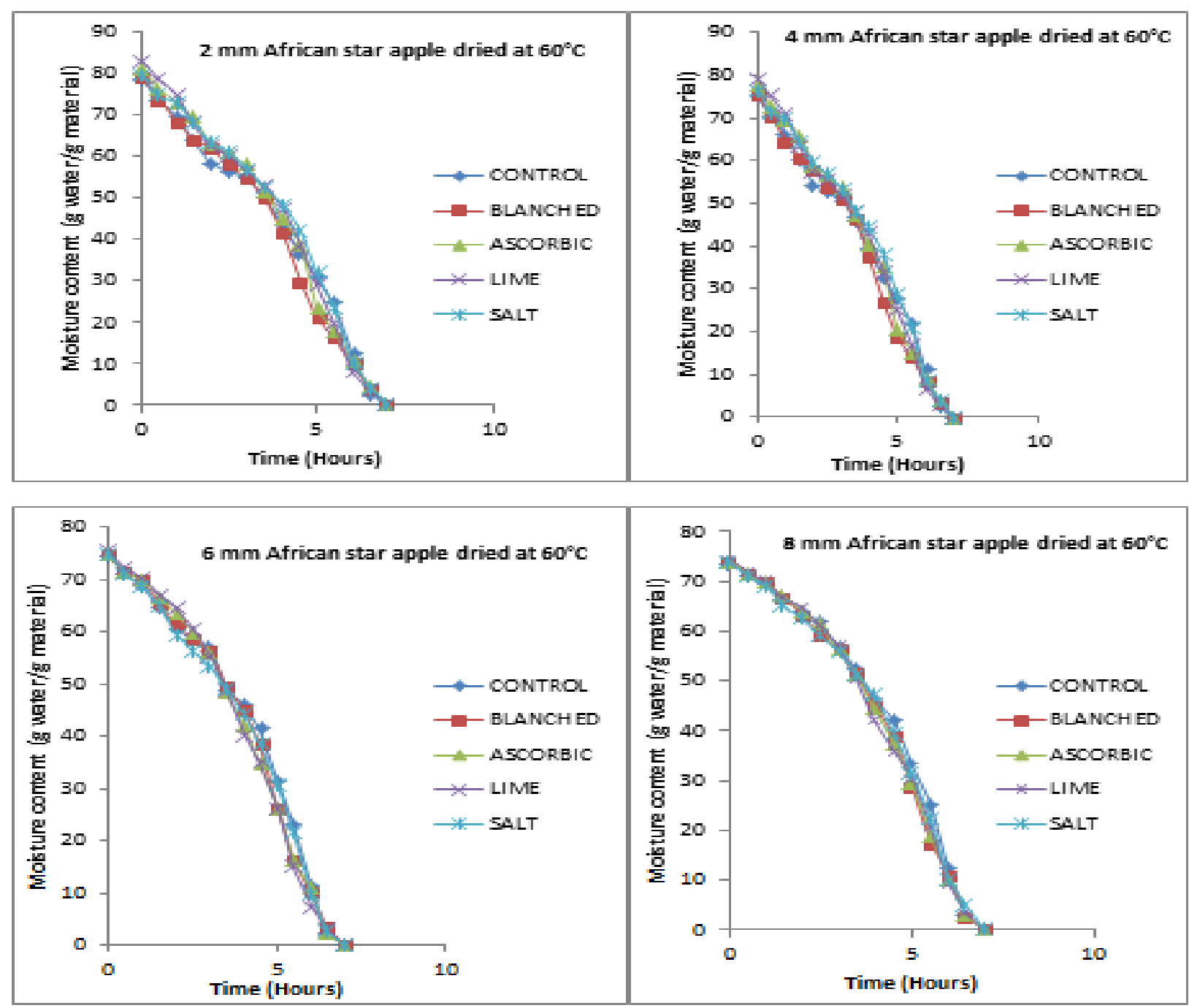

Figure-3. Drying Curves for African Star Apple Flesh of $2 \mathrm{~mm}, 4 \mathrm{~mm}, 6 \mathrm{~mm}$ and $8 \mathrm{~mm}$ Thicknesses Dried at $60{ }^{\circ} \mathrm{C}$. Source: Authors' Findings.

The downward trends of the drying curves show that moisture content reduces with increasing drying time. The highest moisture loss was observed at the early period of drying due to the removal of free water present at the surface of the fruits. Over the course of the drying period, the moisture removal was observed to reduce; the 
temperature of drying not commensurate to the amount of moisture being removed. At no point in the drying operations was the moisture removal at a constant rate. This confirms that the whole drying operation of the fruit samples largely took place in the falling rate period. This is in line with the results of Taiwo and Adeyemi [10] and Tunde-Akintunde [11] on banana slices and chilli peppers, respectively.

The slice thicknesses of the samples and higher drying temperatures were also observed to have effects on the rate of moisture removal; which invariably affected the overall drying process. Faster drying rates were observed at $2 \mathrm{~mm}$ and $4 \mathrm{~mm}$ thicknesses compared to the $6 \mathrm{~mm}$ and $8 \mathrm{~mm}$ thicknesses for drying of the African star apple. This result corroborated with Hussein, et al. [12] findings in which the drying time reduced significantly as the thickness of slices decreases, because the resistance to moisture movement is relatively higher in thicker slices than in thinner ones. Also, the rate of drying at $60{ }^{\circ} \mathrm{C}$ was faster as shown in Figure 3. This was due to high temperature gradients created by higher temperature which ease the migration of water from the inner part to the surface to get evaporated. The ease of this migration depends on the porosity of the samples, drying temperatures and the surface area available as reported by Hussein, et al. [12]. The study also confirmed the reports of Tunde-Akintunde and Oke [13] and Sobukola [14] on plantain and apple thin layer drying, respectively. This was explained as higher temperatures leading to faster removal of moisture from food materials.

\subsection{Effects of Temperature and Pretreatments on Drying Rate}

The moisture contents of the fruits were observed to reduce with increase in the drying time. The drying rates of the pretreated samples were higher than the drying rates of the control sample in most of the drying conditions. However, these were not in all cases as the pretreatments were not significant in some drying conditions. Figure 4 -6 show the drying rate curves for the African star apple flesh. From the figures, the drying rates of the pretreated African star apple flesh were observed to consistently having higher drying rates; with the blanching pretreatment being more predominant. This may be attributed to the softer and looser structure of the flesh of the fruit, an observation reported by Doymaz [15] on carrot pomace. The effect of blanching increasing moisture loss and drying rates of agricultural materials has also been reported by Taiwo and Adeyemi [10]. Kaymak-Ertekin [16] reported that blanching improves the drying rates of carrots because blanching increases the porosity of cell walls, leading to faster movement of water away from the food. This observation is also in agreement with the work of Akintunde, et al. [17] on the blanching of green pepper; that blanching operation generally increases the drying rate.
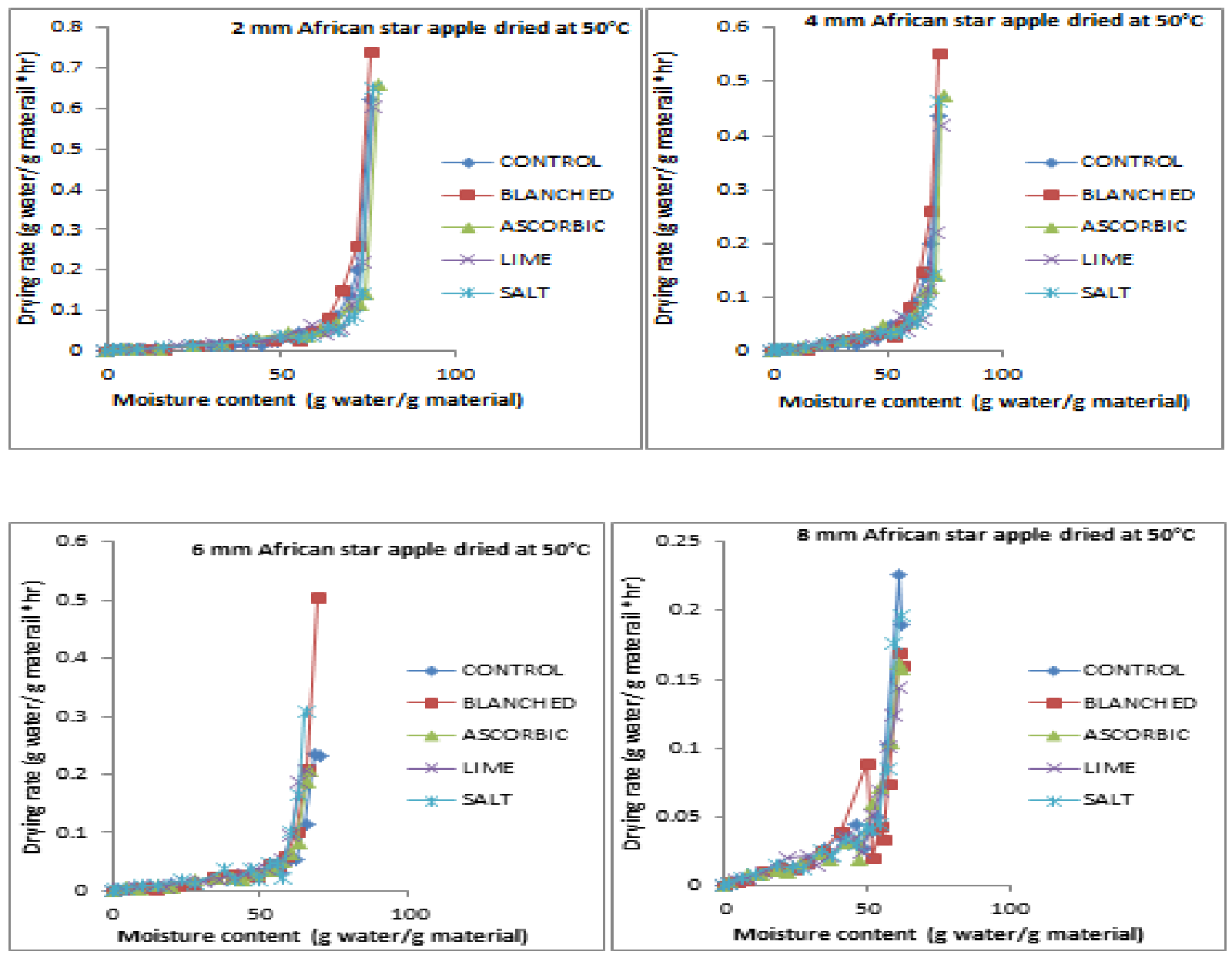

Figure-4. Drying Rate Curves for $2 \mathrm{~mm}, 4 \mathrm{~mm}, 6 \mathrm{~mm}$ and $8 \mathrm{~mm}$ African Star Apple Flesh Dried at $50{ }^{\circ} \mathrm{C}$. Source: Authors' Findings. 

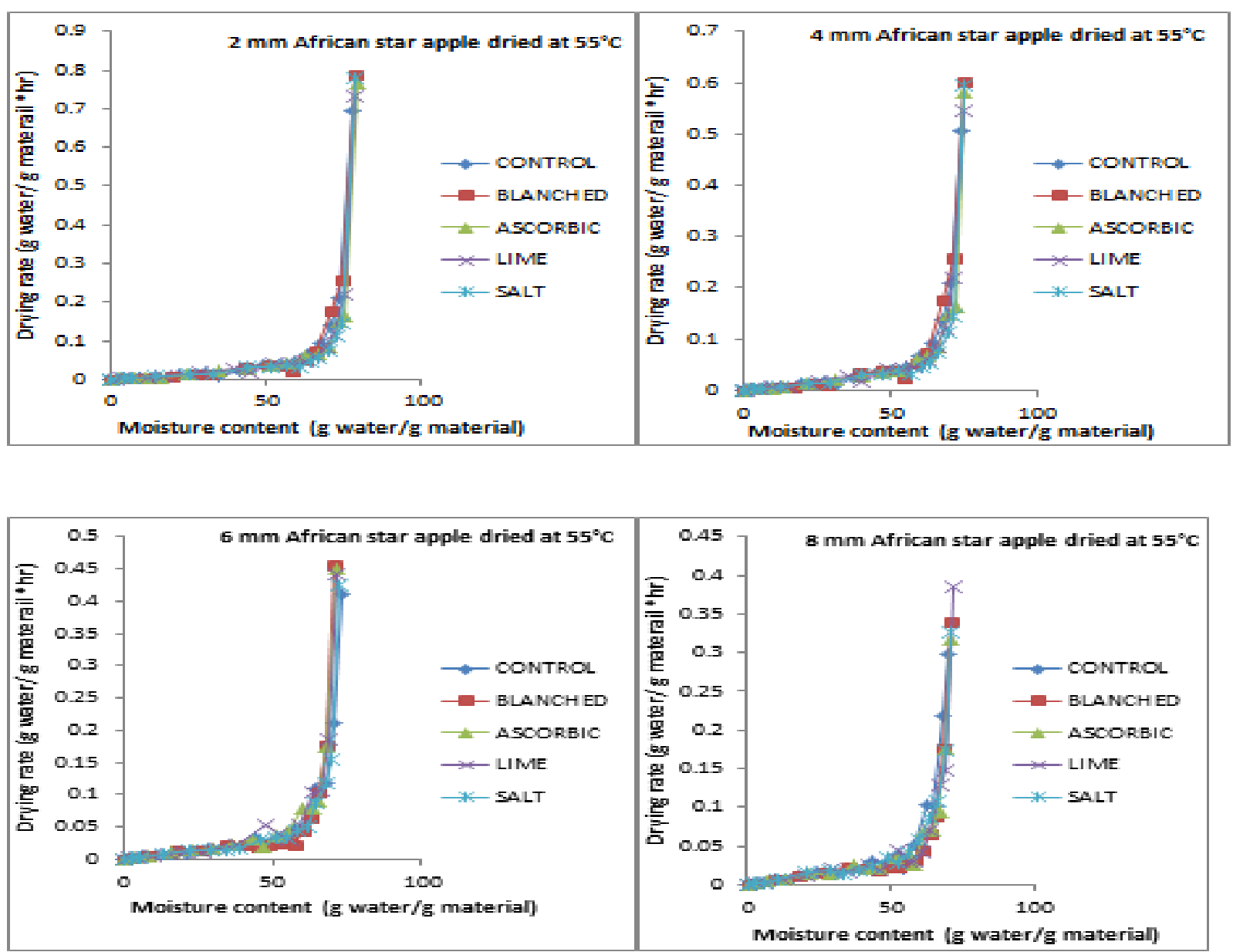

Figure-5. Drying Rate Curves for $2 \mathrm{~mm}, 4 \mathrm{~mm}, 6 \mathrm{~mm}$ and $8 \mathrm{~mm}$ African Star Apple Flesh Dried at $55^{\circ} \mathrm{C}$. Source: Authors' Findings.
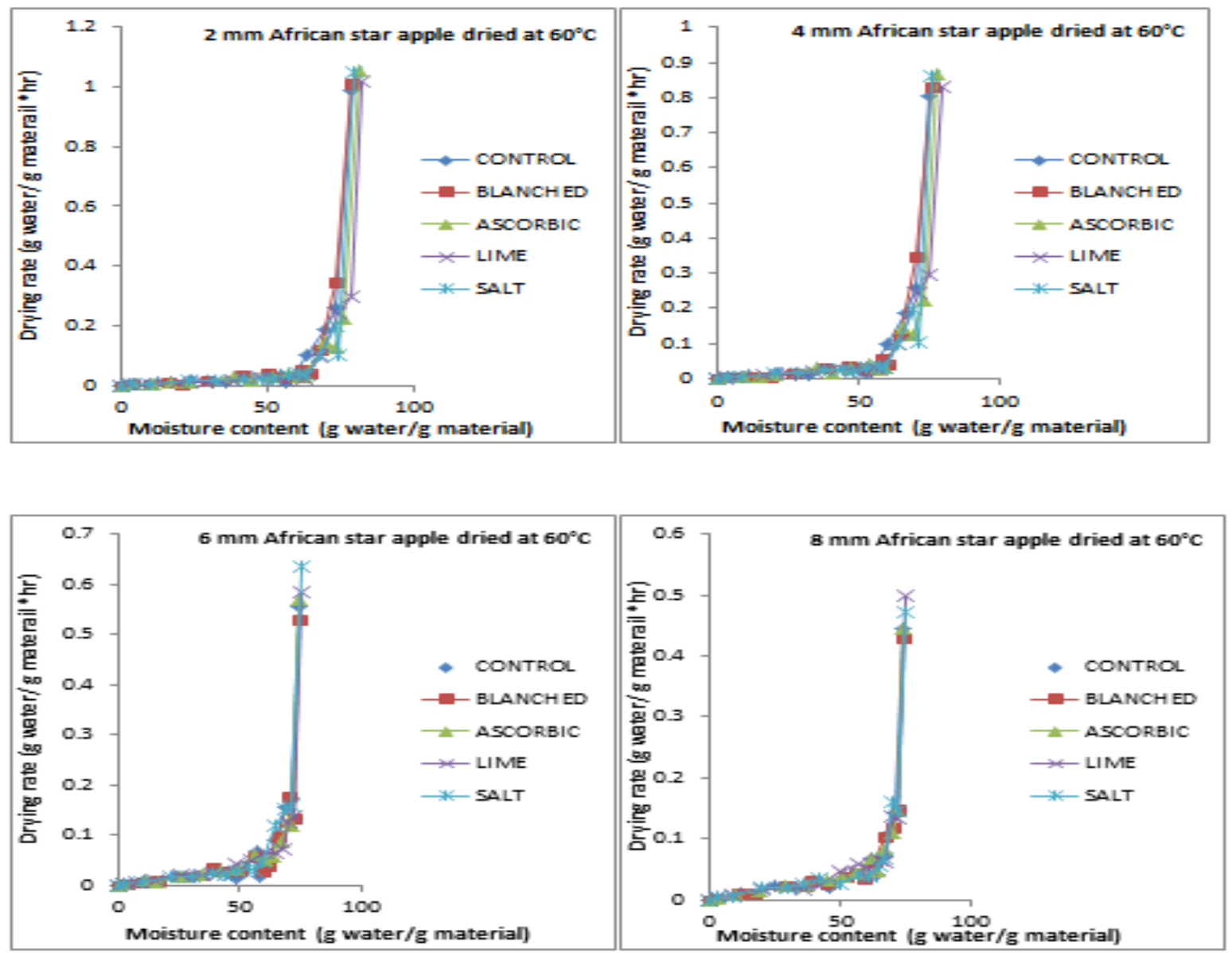

Figure-6. Drying Rate Curves for $2 \mathrm{~mm}, 4 \mathrm{~mm}, 6 \mathrm{~mm}$ and $8 \mathrm{~mm}$ African Star Apple Flesh Dried at $60^{\circ} \mathrm{C}$. Source: Authors' Findings.

The other pretreatment methods had slightly higher rates than the control samples, but not as predominant as the blanched samples. A similar observation was also made by Abano [4] on drying of pineapples with different pretreatments. It was reported that there was an initial faster rate of drying with ascorbic acid pretreatment which was later reduced due to the leaching effects of ascorbic acid. Salt pretreatment was also found to have a high drying rate in the study. The high drying rate was observed to be as a result of common salt made of sodium chloride in an acid-base reaction thus, heating caused the loss of moisture. The high drying rate of the salt pretreatment was attributed to this reaction. 


\subsection{Effect of Temperature and Pretreatment on Ascorbic Acid Retention}

In the drying experiments, the fruits were dried by the reduction of their moisture contents; however, this was in tandem with the loss of valuable nutrients such as ascorbic acid content of the fruits. An important indicator of the efficient drying of the fruits is the ascorbic acid retention of the drying process. The results for the ascorbic acid retention of the drying experiments are shown in Table 1 . The total ascorbic acid content of fresh flesh was found to be $24.37 \mathrm{mg} / 100 \mathrm{~g}$. The total ascorbic acid retention showed a consistent trend of samples pretreated with lime having highest values, followed by ascorbic acid, control and salt solution respectively. The values ranged from $14.75 \mathrm{mg} / 100 \mathrm{~g}$ to $19.17 \mathrm{mg} / 100 \mathrm{~g}$ at $50{ }^{\circ} \mathrm{C}, 14.02 \mathrm{mg} / 100 \mathrm{~g}$ to $18.48 \mathrm{mg} / 100 \mathrm{~g}$ at $55^{\circ} \mathrm{C}$ and $13.72 \mathrm{mg} / 100 \mathrm{~g}$ to $18.15 \mathrm{mg} / 100 \mathrm{~g}$ at $60{ }^{\circ} \mathrm{C}$. The results also showed that there was higher ascorbic acid retention at lower temperatures and smaller thicknesses compared to higher temperatures and larger thicknesses. This was highlighted by the highest ascorbic acid retention at $50{ }^{\circ} \mathrm{C}$ and $2 \mathrm{~mm}$ thickness compared to the lowest at $60{ }^{\circ} \mathrm{C}$ and $8 \mathrm{~mm}$ thickness.

Table-1. Ascorbic Acid Content of Dried African Star Apple Flesh.

\begin{tabular}{|c|c|c|c|c|c|}
\hline \multirow[b]{2}{*}{ Temperature } & \multirow[b]{2}{*}{ Pretreatment } & \multicolumn{4}{|c|}{ Ascorbic acid content (mg/100 g) } \\
\hline & & $2 \mathrm{~mm}$ & $4 \mathrm{~mm}$ & $6 \mathrm{~mm}$ & $8 \mathrm{~mm}$ \\
\hline \multirow[t]{5}{*}{$50^{\circ} \mathrm{C}$} & Control & $17.29 \pm 0.11^{\mathrm{c}}$ & $16.89 \pm 0.08^{c}$ & $16.61 \pm 0.08^{c}$ & $15.89 \pm 0.07^{\natural}$ \\
\hline & Blanched & $16.79 \pm 0.24^{\mathrm{b}}$ & $16.38 \pm 0.32^{\mathrm{b}}$ & $16.39 \pm 0.08^{b}$ & $15.49 \pm 0.29$ \\
\hline & Ascorbic & $18.10 \pm 0.07^{\mathrm{d}}$ & $17.68 \pm 0.08^{d}$ & $17.12 \pm 0.08^{d}$ & $16.59 \pm 0.07$ \\
\hline & Lime & $19.17 \pm 0.17^{\mathrm{e}}$ & $18.83 \pm 0.08^{\mathrm{e}}$ & $17.58 \pm 0.07^{\mathrm{e}}$ & $17.17 \pm 0.08^{\circ}$ \\
\hline & Salt & $16.21 \pm 0.08^{a}$ & $15.81 \pm 0.12^{\mathrm{a}}$ & $14.74 \pm 0.08^{a}$ & $14.75 \pm 0.78$ \\
\hline \multirow[t]{5}{*}{$55^{\circ} \mathrm{C}$} & Control & $16.94 \pm 0.04^{\mathrm{c}}$ & $16.51 \pm 0.03^{\mathrm{c}}$ & $16.18 \pm 0.25^{\mathrm{c}}$ & $15.58 \pm 0.08$ \\
\hline & Blanched & $16.76 \pm 0.03^{b}$ & $16.33 \pm 0.06^{b}$ & $15.49 \pm 0.07^{\mathrm{b}}$ & $15.31 \pm 0.16^{\mathrm{b}}$ \\
\hline & Ascorbic & $17.83 \pm 0.09^{d}$ & $17.44 \pm 0.07^{\mathrm{d}}$ & $16.84 \pm 0.08^{d}$ & $16.46 \pm 0.07^{\circ}$ \\
\hline & Lime & $18.48 \pm 0.08^{\mathrm{e}}$ & $18.07 \pm 0.09^{\mathrm{e}}$ & $17.32 \pm 0.06^{\mathrm{e}}$ & $16.81 \pm 0.09$ \\
\hline & Salt & $15.84 \pm 0.21^{\mathrm{a}}$ & $15.49 \pm 0.08^{a}$ & $14.37 \pm 0.08^{a}$ & $14.02 \pm 0.11$ \\
\hline \multirow[t]{5}{*}{$60^{\circ} \mathrm{C}$} & Control & $17.64 \pm 0.02^{\mathrm{c}}$ & $16.39 \pm 0.09^{\mathrm{c}}$ & $15.89 \pm 0.63^{c}$ & $15.48 \pm 0.07^{\circ}$ \\
\hline & Blanched & $16.67 \pm 0.08^{b}$ & $16.19 \pm 0.05^{b}$ & $15.25 \pm 0.09^{b}$ & $15.25 \pm 0.09^{b}$ \\
\hline & Ascorbic & $17.64 \pm 0.02^{\mathrm{c}}$ & $17.19 \pm 0.07^{\mathrm{d}}$ & $16.74 \pm 0.07^{\mathrm{d}}$ & $16.21 \pm 0.07^{\circ}$ \\
\hline & Lime & $18.15 \pm 0.07^{\mathrm{d}}$ & $17.73 \pm 0.08^{d}$ & $17.19 \pm 0.07^{\mathrm{e}}$ & $16.63 \pm 0.07$ \\
\hline & Salt & $15.25 \pm 0.03^{\mathrm{a}}$ & $14.79 \pm 0.06^{\mathrm{a}}$ & $14.15 \pm 0.09^{\mathrm{a}}$ & $13.72 \pm 0.73^{\circ}$ \\
\hline
\end{tabular}

Note: Means within the same column at the same temperature with different alphabet(s) are significantly different at $\mathrm{p}<0.05$.

Source: Authors' Findings.'

The results showed a significant reduction in the ascorbic acid content of the dried samples, with increasing temperature and thickness also having great significance. The heating foods at higher temperatures cause losses of ascorbic acid because it is heat labile. The findings of Gupta, et al. [18] corroborates this claim, where drying at temperatures above $60{ }^{\circ} \mathrm{C}$ resulted in substantial ascorbic acid losses in the drying of cauliflower. It was also reported that prolonged exposure to higher temperatures destroys compounds in fruits. An explanation on the variations in ascorbic acid was given by Garba and Kaur [19] where the variations were attributed to the different pre-treatments used. Joshi, et al. [20] also proposed that the ascorbic acid losses during most drying methods could be as a result of oxidation of ascorbic acid at high temperatures, which also supports the results of these drying operations.

The ascorbic acid reduction of the fruit samples was consistent across the samples with pretreatments and control samples. This showed that hot air drying resulted in ascorbic acid degradation in all the samples. The higher values of ascorbic acid retention recorded for the lime and ascorbic acid pretreatment could be due to them being high sources of ascorbic acid. This could reduce the degradation kinetics of the ascorbic acid in the fruits during the drying operation. The control samples showed higher ascorbic acid retention than the blanched and salt pretreatments. This may be due to enzymatic and chemical degradation as well as leaching and heating operations, a similar observation noted by Wawire, et al. [21] and Toor and Savage [22]. The results of these experiments were higher than the results reported by Ruvini, et al. [23] on similar drying operations with similar pretreatments. The observations made by Demiray and Tulek [24] on ascorbic acid retention in fruits at temperatures below $70{ }^{\circ} \mathrm{C}$ also support the ascorbic acid retention values for these experiments. The lower values for the salt pretreated samples across the fruits may be due to the inhibiting effect salt has on ascorbic acid [25, $26]$.

\subsection{Effect of Temperature and Pretreatment on Colour Retention}

The final colour of the dried fruits is of great importance to the consumers. Colour is one of the subjective quality characteristics which indicate the level of effects of the drying methods, the pretreatment effects or conditions. Hence, colour is of great importance in deciding the preference of consumers [27]. Tables $2-5$ show the colour changes in the dried African star apple. The tables display the values for $\mathrm{L}^{*}, \mathrm{a}^{*}, \mathrm{~b}^{*}$ and $\Delta \mathrm{E}$ which indicate the lightness, redness, yellowness and change in colour values respectively. The $\mathrm{L}^{*}, \mathrm{a}^{*}, \mathrm{~b}^{*}$ and $\Delta \mathrm{E}$ values for African star apple were 40.29, 15.69, 18.54 and 37.78. The dried fruits all showed considerably lower values for all the parameters compared to the fresh samples. This is an indication that the slice thickness and pre-treatments were not significant because the colour changes were random and no specific sequence could be ascertained. The best colour retention for the African star apple were salt pre-treatment at $50{ }^{\circ} \mathrm{C}$ for $2 \mathrm{~mm}$, salt at $50{ }^{\circ} \mathrm{C}$ for $4 \mathrm{~mm}$, ascorbic at $50{ }^{\circ} \mathrm{C}$ for $6 \mathrm{~mm}$ and salt at $50{ }^{\circ} \mathrm{C}$ for $8 \mathrm{~mm}$. 
Table-2. Colour Changes for Dried African Star Apple Flesh of $2 \mathrm{~mm}$ Thickness.

\begin{tabular}{c|c|c|c|c|c}
\hline Temperature & Pre-treatment & $\mathbf{L}^{*}$ & $\mathbf{a}^{*}$ & $\mathbf{b}^{*}$ & $\Delta \mathbf{E}$ \\
\hline $50{ }^{\circ} C$ & Control & $28.29 \pm 0.62^{\mathrm{b}}$ & $11.44 \pm 0.90^{\mathrm{c}}$ & $5.95 \pm 0.87^{\mathrm{b}}$ & $18.52 \pm 1.34^{\mathrm{bc}}$ \\
\hline & Blanched & $24.93 \pm 0.97^{\mathrm{a}}$ & $9.63 \pm 0.64^{\mathrm{b}}$ & $4.17 \pm 1.38^{\mathrm{b}}$ & $16.33 \pm 1.77^{\mathrm{ab}}$ \\
\hline & Ascorbic & $28.28 \pm 3.60^{\mathrm{b}}$ & $7.12 \pm 0.17^{\mathrm{a}}$ & $1.90 \pm 1.43^{\mathrm{a}}$ & $16.22 \pm 3.56^{\mathrm{ab}}$ \\
\hline & Lime & $24.33 \pm 0.66^{\mathrm{a}}$ & $6.64 \pm 1.01^{\mathrm{a}}$ & $1.90 \pm 1.84^{\mathrm{a}}$ & $13.14 \pm 1.98^{\mathrm{a}}$ \\
\hline & Salt & $32.31 \pm 1.61^{\mathrm{c}}$ & $7.70 \pm 0.52^{\mathrm{a}}$ & $5.74 \pm 0.07^{\mathrm{b}}$ & $21.57 \pm 1.03^{\mathrm{c}}$ \\
\hline & Control & $27.66 \pm 2.77^{\mathrm{b}}$ & $11.29 \pm 0.76^{\mathrm{b}}$ & $5.32 \pm 1.94^{\mathrm{d}}$ & $17.71 \pm 3.16^{\mathrm{b}}$ \\
\hline & Blanched & $24.37 \pm 0.60^{\mathrm{a}}$ & $7.32 \pm 0.53^{\mathrm{a}}$ & $2.04 \pm 0.48^{\mathrm{ab}}$ & $13.54 \pm 0.58^{\mathrm{a}}$ \\
\hline & Ascorbic & $26.62 \pm 0.98^{\mathrm{ab}}$ & $6.59 \pm 0.47^{\mathrm{a}}$ & $1.45 \pm 0.77^{\mathrm{a}}$ & $14.48 \pm 1.04^{\mathrm{a}}$ \\
\hline & Lime & $26.61 \pm 1.65^{\mathrm{ab}}$ & $6.96 \pm 0.44^{\mathrm{a}}$ & $3.23 \pm 0.49^{\mathrm{bc}}$ & $15.65 \pm 1.28^{\mathrm{ab}}$ \\
\hline & Salt & $28.36 \pm 0.81^{\mathrm{b}}$ & $6.99 \pm 1.04^{\mathrm{a}}$ & $3.65 \pm 0.27^{\mathrm{c}}$ & $17.17 \pm 0.49^{\mathrm{b}}$ \\
\hline & Control & $28.62 \pm 1.73^{\mathrm{c}}$ & $7.96 \pm 0.61^{\mathrm{b}}$ & $4.31 \pm 0.70^{\mathrm{c}}$ & $16.45 \pm 13.59^{\mathrm{d}}$ \\
\hline & Blanched & $26.54 \pm 0.26^{\mathrm{ab}}$ & $6.79 \pm 0.06^{\mathrm{a}}$ & $2.84 \pm 0.60^{\mathrm{b}}$ & $13.57 \pm 0.53^{\mathrm{b}}$ \\
\hline & Ascorbic & $24.97 \pm 0.62^{\mathrm{a}}$ & $6.77 \pm 0.15^{\mathrm{a}}$ & $1.88 \pm 0.30^{\mathrm{a}}$ & $11.84 \pm 0.66^{\mathrm{a}}$ \\
\hline & Lime & $26.82 \pm 1.76^{\mathrm{abc}}$ & $8.27 \pm 0.52^{\mathrm{b}}$ & $3.86 \pm 0.13^{\mathrm{c}}$ & $14.95 \pm 1.11^{\mathrm{c}}$ \\
\hline & Salt & $28.39 \pm 1.13^{\mathrm{bc}}$ & $7.90 \pm 0.44^{\mathrm{b}}$ & $4.51 \pm 0.09^{\mathrm{c}}$ & $16.30 \pm 0.82^{\mathrm{d}}$ \\
\hline
\end{tabular}

Note: Means within the same column at the same temperature with different alphabet(s) are significantly different at $\mathrm{p}<0.05$.

Source: Authors' Findings.

Table-3. Colour Changes for Dried African Star Apple Flesh of $4 \mathrm{~mm}$ Thickness.

\begin{tabular}{c|c|c|c|c|c}
\multicolumn{6}{c}{ Table-3. Colour Changes for Dried African Star Apple Flesh of 4 mm Thickness. } \\
\hline Temperature & Pre-treatment & $\mathbf{L}^{*}$ & $\mathbf{a}^{*}$ & $\mathbf{b}^{*}$ & $\Delta \mathbf{E}$ \\
\hline $50^{\circ} \mathrm{C}$ & Control & $27.01 \pm 0.62^{\mathrm{ab}}$ & $10.16 \pm 0.90^{\mathrm{b}}$ & $4.67 \pm 0.87^{\mathrm{ab}}$ & $17.24 \pm 1.34^{\mathrm{a}}$ \\
\hline & Blanched & $26.21 \pm 0.97^{\mathrm{a}}$ & $10.91 \pm 0.64^{\mathrm{b}}$ & $5.45 \pm 1.38^{\mathrm{ab}}$ & $17.61 \pm 1.77^{\mathrm{a}}$ \\
\hline & Ascorbic & $29.56 \pm 3.60^{\mathrm{b}}$ & $8.40 \pm 0.17^{\mathrm{a}}$ & $3.18 \pm 1.43^{\mathrm{a}}$ & $17.50 \pm 3.56^{\mathrm{a}}$ \\
\hline & Lime & $25.61 \pm 0.66^{\mathrm{a}}$ & $7.92 \pm 1.01^{\mathrm{a}}$ & $3.18 \pm 1.84^{\mathrm{a}}$ & $14.42 \pm 1.98^{\mathrm{a}}$ \\
\hline & Salt & $33.59 \pm 1.61^{\mathrm{c}}$ & $8.98 \pm 0.52^{\mathrm{a}}$ & $7.02 \pm 0.07^{\mathrm{c}}$ & $22.85 \pm 1.03^{\mathrm{b}}$ \\
\hline & Control & $26.38 \pm 2.77^{\mathrm{a}}$ & $10.01 \pm 0.76^{\mathrm{b}}$ & $4.04 \pm 1.94^{\mathrm{ab}}$ & $16.43 \pm 3.16^{\mathrm{ab}}$ \\
\hline & Blanched & $25.65 \pm 0.60^{\mathrm{a}}$ & $8.60 \pm 0.53^{\mathrm{a}}$ & $3.32 \pm 0.48^{\mathrm{ab}}$ & $14.82 \pm 0.58^{\mathrm{a}}$ \\
\hline & Ascorbic & $27.90 \pm 0.98^{\mathrm{ab}}$ & $7.87 \pm 0.47^{\mathrm{a}}$ & $2.73 \pm 0.79^{\mathrm{a}}$ & $15.76 \pm 1.04^{\mathrm{a}}$ \\
\hline & Lime & $27.89 \pm 1.65^{\mathrm{ab}}$ & $8.24 \pm 0.44^{\mathrm{a}}$ & $4.51 \pm 0.49^{\mathrm{b}}$ & $16.93 \pm 1.28^{\mathrm{ab}}$ \\
\hline & Salt & $29.64 \pm 0.81^{\mathrm{b}}$ & $8.27 \pm 1.04^{\mathrm{a}}$ & $4.93 \pm 0.27^{\mathrm{b}}$ & $18.45 \pm 0.49^{\mathrm{b}}$ \\
\hline & Control & $27.34 \pm 1.73^{\mathrm{c}}$ & $6.68 \pm 0.61^{\mathrm{b}}$ & $3.03 \pm 0.70^{\mathrm{c}}$ & $15.17 \pm 0.97^{\mathrm{d}}$ \\
\hline & Blanched & $25.26 \pm 0.26^{\mathrm{ab}}$ & $5.51 \pm 0.06^{\mathrm{a}}$ & $1.56 \pm 0.60^{\mathrm{b}}$ & $12.30 \pm 0.53^{\mathrm{b}}$ \\
\hline & Ascorbic & $23.69 \pm 0.62^{\mathrm{a}}$ & $5.50 \pm 0.15^{\mathrm{a}}$ & $0.59 \pm 0.30^{\mathrm{a}}$ & $10.56 \pm 0.66^{\mathrm{a}}$ \\
\hline & Lime & $25.54 \pm 1.76^{\mathrm{abc}}$ & $6.99 \pm 0.52^{\mathrm{b}}$ & $2.58 \pm 0.13^{\mathrm{c}}$ & $13.67 \pm 1.11^{\mathrm{c}}$ \\
\hline & Salt & $27.11 \pm 1.13^{\mathrm{bc}}$ & $6.62 \pm 0.44^{\mathrm{b}}$ & $3.23 \pm 0.09^{\mathrm{c}}$ & $15.02 \pm 0.82^{\mathrm{d}}$ \\
\hline
\end{tabular}

Note: Means within the same column at the same temperature with different alphabet(s) are significantly different at $\mathrm{p}<0.05$. Source: Authors' Findings.

Table-4. Colour Changes for Dried African Star Apple Flesh of $6 \mathrm{~mm}$ Thickness.

\begin{tabular}{c|c|c|c|c|c}
\hline Temperature & Pre-treatment & $\mathbf{L}^{*}$ & $\mathbf{a}^{*}$ & $\mathbf{b}^{*}$ & $\Delta \mathbf{E}$ \\
\hline $50{ }^{\circ} \mathrm{C}$ & Control & $28.73 \pm 1.24^{\mathrm{a}}$ & $8.94 \pm 0.40^{\mathrm{b}}$ & $5.74 \pm 1.97^{\mathrm{a}}$ & $18.51 \pm 2.18^{\mathrm{a}}$ \\
\hline & Blanched & $30.00 \pm 3.69^{\mathrm{a}}$ & $8.16 \pm 0.18^{\mathrm{a}}$ & $4.66 \pm 1.74^{\mathrm{a}}$ & $18.55 \pm 3.75^{\mathrm{a}}$ \\
\hline & Ascorbic & $29.53 \pm 2.08^{\mathrm{a}}$ & $7.80 \pm 0.79^{\mathrm{a}}$ & $5.52 \pm 0.13^{\mathrm{a}}$ & $18.60 \pm 1.32^{\mathrm{a}}$ \\
\hline & Lime & $26.52 \pm 0.23^{\mathrm{a}}$ & $8.15 \pm 0.25^{\mathrm{a}}$ & $3.59 \pm 0.51^{\mathrm{a}}$ & $15.36 \pm 0.30^{\mathrm{a}}$ \\
\hline & Salt & $26.88 \pm 1.82^{\mathrm{a}}$ & $7.58 \pm 0.19^{\mathrm{a}}$ & $3.33 \pm 2.21^{\mathrm{a}}$ & $15.25 \pm 2.65^{\mathrm{a}}$ \\
\hline & Control & $24.66 \pm 0.76^{\mathrm{a}}$ & $6.49 \pm 0.68^{\mathrm{a}}$ & $1.68 \pm 1.46^{\mathrm{a}}$ & $12.28 \pm 1.65^{\mathrm{a}}$ \\
\hline & Blanched & $27.75 \pm 1.06^{\mathrm{b}}$ & $5.72 \pm 0.44^{\mathrm{a}}$ & $2.24 \pm 0.71^{\mathrm{ab}}$ & $14.66 \pm 1.34^{\mathrm{ab}}$ \\
\hline & Ascorbic & $24.22 \pm 0.17^{\mathrm{a}}$ & $7.22 \pm 0.21^{\mathrm{ab}}$ & $2.95 \pm 0.27^{\mathrm{ab}}$ & $13.07 \pm 0.27^{\mathrm{ab}}$ \\
\hline & Lime & $27.79 \pm 1.86^{\mathrm{b}}$ & $8.62 \pm 0.27^{\mathrm{b}}$ & $4.73 \pm 0.78^{\mathrm{b}}$ & $17.14 \pm 1.71^{\mathrm{b}}$ \\
\hline & Salt & $27.68 \pm 3.32^{\mathrm{b}}$ & $6.86 \pm 1.91^{\mathrm{a}}$ & $4.02 \pm 3.48^{\mathrm{ab}}$ & $15.98 \pm 5.12^{\mathrm{ab}}$ \\
\hline & Control & $27.97 \pm 0.54^{\mathrm{c}}$ & $4.72 \pm 0.69^{\mathrm{a}}$ & $0.64 \pm 0.49^{\mathrm{a}}$ & $13.73 \pm 0.36^{\mathrm{a}}$ \\
\hline & Blanched & $24.90 \pm 0.71^{\mathrm{a}}$ & $6.08 \pm 1.78^{\mathrm{ab}}$ & $1.76 \pm 1.81^{\mathrm{a}}$ & $12.44 \pm 2.16^{\mathrm{a}}$ \\
\hline & Ascorbic & $26.39 \pm 0.37^{\mathrm{ab}}$ & $5.09 \pm 0.38^{\mathrm{ab}}$ & $1.66 \pm 0.43^{\mathrm{a}}$ & $13.11 \pm 0.52^{\mathrm{a}}$ \\
\hline & Lime & $26.68 \pm 1.70^{\mathrm{bc}}$ & $4.88 \pm 0.31^{\mathrm{ab}}$ & $4.09 \pm 4.69^{\mathrm{a}}$ & $13.26 \pm 1.54^{\mathrm{a}}$ \\
\hline & Salt & $25.30 \pm 1.07^{\mathrm{ab}}$ & $6.28 \pm 0.57^{\mathrm{b}}$ & $1.82 \pm 0.47^{\mathrm{a}}$ & $12.59 \pm 1.17^{\mathrm{a}}$ \\
\hline
\end{tabular}

Note: Means within the same column at the same temperature with different alphabet(s) are significantly different at $\mathrm{p}<0.05$ Source: Authors' Findings.

Table-5. Colour Changes for Dried African Star Apple Flesh of $8 \mathrm{~mm}$ Thickness.

\begin{tabular}{c|c|c|c|c|c}
\hline Temperature & Pre-treatment & $\mathbf{L}^{*}$ & $\mathbf{a}^{*}$ & $\mathbf{b}^{*}$ & $\Delta \mathbf{E}$ \\
\hline $50^{\circ} \mathrm{C}$ & Control & $24.42 \pm 0.37^{\mathrm{a}}$ & $7.82 \pm 0.60^{\mathrm{b}}$ & $1.71 \pm 0.81^{\mathrm{a}}$ & $12.70 \pm 0.82^{\mathrm{a}}$ \\
\hline & Blanched & $29.16 \pm 4.47^{\mathrm{b}}$ & $7.82 \pm 0.24^{\mathrm{b}}$ & $4.41 \pm 1.99^{\mathrm{b}}$ & $17.70 \pm 4.42^{\mathrm{b}}$ \\
\hline & Ascorbic & $24.88 \pm 0.54^{\mathrm{a}}$ & $7.79 \pm 0.60^{\mathrm{b}}$ & $1.79 \pm 0.60^{\mathrm{a}}$ & $13.02 \pm 0.35^{\mathrm{a}}$ \\
\hline & Lime & $28.58 \pm 1.82^{\mathrm{b}}$ & $5.48 \pm 0.51^{\mathrm{a}}$ & $2.66 \pm 0.59^{\mathrm{a}}$ & $15.53 \pm 1.67^{\mathrm{ab}}$ \\
\hline & Salt & $29.24 \pm 1.95^{\mathrm{b}}$ & $7.70 \pm 1.37^{\mathrm{b}}$ & $5.15 \pm 0.69^{\mathrm{b}}$ & $18.14 \pm 1.54^{\mathrm{b}}$ \\
\hline & Control & $28.50 \pm 0.36^{\mathrm{a}}$ & $7.54 \pm 0.30^{\mathrm{a}}$ & $3.54 \pm 0.75^{\mathrm{b}}$ & $16.53 \pm 0.46^{\mathrm{a}}$ \\
\hline & Blanched & $27.15 \pm 1.28^{\mathrm{a}}$ & $9.21 \pm 0.59^{\mathrm{b}}$ & $4.92 \pm 1.58^{\mathrm{b}}$ & $17.04 \pm 2.08^{\mathrm{a}}$ \\
\hline & Ascorbic & $27.12 \pm 1.44^{\mathrm{a}}$ & $6.82 \pm 0.64^{\mathrm{a}}$ & $1.87 \pm 0.22^{\mathrm{a}}$ & $14.34 \pm 1.02^{\mathrm{a}}$ \\
\hline & Lime & $27.12 \pm 1.45^{\mathrm{a}}$ & $7.06 \pm 0.68^{\mathrm{a}}$ & $4.22 \pm 1.48^{\mathrm{b}}$ & $16.23 \pm 3.13^{\mathrm{a}}$ \\
\hline & Salt & $27.12 \pm 1.46^{\mathrm{a}}$ & $7.36 \pm 0.29^{\mathrm{a}}$ & $4.53 \pm 0.58^{\mathrm{b}}$ & $16.32 \pm 1.93^{\mathrm{a}}$ \\
\hline & Control & $27.74 \pm 2.09^{\mathrm{a}}$ & $7.34 \pm 1.16^{\mathrm{b}}$ & $4.26 \pm 1.98^{\mathrm{b}}$ & $16.31 \pm 3.03^{\mathrm{b}}$ \\
\hline & Blanched & $25.66 \pm 3.34^{\mathrm{a}}$ & $6.42 \pm 0.86^{\mathrm{ab}}$ & $1.08 \pm 0.40^{\mathrm{a}}$ & $12.84 \pm 2.13^{\mathrm{a}}$ \\
\hline & Ascorbic & $25.04 \pm 0.89^{\mathrm{a}}$ & $5.30 \pm 0.14^{\mathrm{a}}$ & $0.80 \pm 0.86^{\mathrm{a}}$ & $11.59 \pm 1.18^{\mathrm{a}}$ \\
\hline & Lime & $25.46 \pm 0.35^{\mathrm{a}}$ & $5.45 \pm 0.66^{\mathrm{a}}$ & $1.81 \pm 0.90^{\mathrm{a}}$ & $12.59 \pm 0.87^{\mathrm{a}}$ \\
\hline & Salt & $26.39 \pm 1.34^{\mathrm{a}}$ & $6.17 \pm 0.71^{\mathrm{ab}}$ & $2.49 \pm 1.91^{\mathrm{ab}}$ & $13.90 \pm 2.34^{\mathrm{ab}}$ \\
\hline
\end{tabular}

Note: Means within the same column at the same temperature with different alphabet(s) are significantly different at $\mathrm{p}<0.05$.

Source: Authors' Findings.

The values recorded were lower compared to values available in literature for drying of similar foods, although their values for fresh samples were higher. Also, comparable data on the drying of African star apple were not 
available. However, Doymaz, et al. 〔28] reported that higher $\mathrm{L}^{*}$ and lower $\mathrm{a}^{*} / \mathrm{b}^{*}$ values are required in dried food materials. The results obtained for the drying in this study are in line with that observation. An explanation for the colour changes experienced is given by Fellows [29] where it was reported that colour changes in fruits and vegetables are caused by heat, oxidation during drying and residual enzyme activity which may cause browning during storage. A similar observation was reported by De-Corcuera, et al. [30] on how blanching pretreatments made samples darker with loss of yellowness which gave lower $\mathrm{L}^{*}$ and $\mathrm{b}^{*}$ values. This was associated to the destruction of pigments by blanching. Ali, et al. [31] reported a similar observation in the drying of guava slices. It was reported that the slices became darker during the drying process and it was attributed to prolonged drying time. It was also reported that temperature increase destroys colour quality; therefore, it was suggested that drying operations should be carried out at lower temperatures to better retain the colour of dried fruits.

\section{Conclusion}

The tropical African star apple fleshes were dried in the cabinet dryer. The drying rate of the African star apple flesh samples decreased as drying rate progressed while it increased with increase in drying temperature. The slice thickness and pretreatments were observed to affect the drying rates, with smaller thicknesses drying faster and blanching pretreatment having the highest drying rate of all. The increase in slice thickness was observed to reduce the drying rate and vice-versa.

The drying time of the fruits ranged between 7 to $8 \mathrm{~h}$. The structures of the samples were however observed to be differ compared to the control samples, despite significant ascorbic acid retention as a result of the pretreatments; especially the lime and ascorbic acid. The pretreatments were observed to help reduce the effect of ascorbic acid degradation by heat. The colour changes of the fruits were also significant as there were significant difference between the values of the fresh samples and the dried products. The ascorbic acid and lime pretreatments however had better colour overall. Drying at $50{ }^{\circ} \mathrm{C}$ with lime pretreatment gave the best result in terms of ascorbic acid retention.

\section{References}

[1] I. Pardeshi, S. Arora, and P. Borker, "Thin-layer drying of green peas and selection of a suitable thin-layer drying model," Drying Technology, vol. 27, pp. 288-295, 2009. Available at: https://doi.org/10.1080/0737393080260645 1.

[2] L. G. Houessou, T. O. Lougbegnon, F. G. Gbesso, L. E. Anagonou, and B. Sinsin, "Ethno-botanical study of the African star apple (Chrysophyllum albidum G. Don) in the Southern Benin (West Africa)," Journal of Ethnobiology and Ethnomedicine, vol. 8, pp. 1-10, 2012. Available at: https://doi.org/10.1186/1746-4269-8-40.

[3] F. A. Bello and A. A. Henry, "Storage effects and the postharvest quality of African star apple fruits (Chrysophyllum africanum) under ambient conditions," African Journal of Food Science and Technology, vol. 6, pp. 35-43, 2015. Available at: https://doi.org/10.14303/ajfst.2015.011.

[4] E. Abano, "Assessments of drying characteristics and physio-organoleptic properties of dried pineapple slices under different pretreatments," Asian Journal of Agricultural Research, vol. 4, pp. 155-161, 2010. Available at: https://doi.org/10.3923/ajar.2010.155.161.

[5] O. R. Karim, "Effect of Pre-Treatment on Drying Kinetics and Quality Attributes of Air-Dehydrated Pineapple Slices," Ph.D, University of Agriculture, Abeokuta, Ogun State, Nigeria, 2005.

AOAC, Official method of analysis. Washington D.C: Association of Official Analytical Chemist, 2010.

T. Tunde-Akintunde, "Mathematical modeling of sun and solar drying of chilli pepper," Renewable Energy, vol. 36, pp. 2139-2145, 2011. Available at: https://doi.org/10.1016/j.renene.2011.01.017.

[8] I. Doymaz, "Drying of potato slices: Effect of pre-treatments and mathematical modeling," Journal of Food Processing and Preservation, vol. 36, pp. 310-319, 2011.

[9] D. Ashebir, K. Jezik, H. Weingartemann, and R. Gretzmacher, "Change in color and other fruit quality characteristics of tomato cultivars after hot-air drying at low final-moisture content," International Journal of Food Sciences and Nutrition, vol. 60, pp. 308-315, 2009. Available at: https://doi.org/10.1080/09637480903114128.

[10] K. A. Taiwo and O. Adeyemi, "Influence of blanching on the drying and rehydration of banana slices," African Journal of Food Science, vol. 3, pp. 307-315, 2009.

[11] T. Tunde-Akintunde, "Effect of pretreatment on drying time and quality of chilli pepper," Journal of Food Processing and Preservation, vol. 34, pp. 595-608, 2010.

[12] J. Hussein, K. Filli, and M. Oke, "Thin layer modelling of hybrid, solar and open sun drying of tomato slices," Research Journal of Food Science and Nutrition, vol. 1, pp. 15-27, 2016.

[13] T. Tunde-Akintunde and M. Oke, "Thin-layer drying characteristics of tiger nut (Cyperus esculentus) seeds," Journal of Food Processing and Preservation, vol. 36, pp. 457-464, 2012. Available at: https://doi.org/10.1111/j.1745-4549.2011.00604.x.

[14] O. Sobukola, "Effect of pre-treatment on the drying characteristics and kinetics of Okra (Abelmoschus esculetus (L.) Moench) slices," International Journal of Food Engineering, vol. 5, pp. 1-22, 2009. Available at: https://doi.org/10.2202/1556-3758.1 191.

[15] İ. Doymaz, "Determination of infrared drying characteristics and modelling of drying behaviour of carrot pomace," Journal of Agricultural Sciences, vol. 19, pp. 44-53, 2013. Available at: https://doi.org/10.1501/tarimbil_0000001227.

[16] F. Kaymak-Ertekin, "Drying and rehydrating kinetics of green and red peppers," Journal of Food Science, vol. 67, pp. 168-175, 2002. Available at: https://doi.org/10.1111/j.1365-2621.2002.tb11378.x.

[17] T. Akintunde, B. Akintunde, and A. Fagbeja, "Effect of blanching methods on drying kinetics of bell paper," African Journal of Food, Agriculture, Nutrition and Development, vol. 11, pp. 5457-5474, 2011.

[18] M. Gupta, V. K. Sehgal, and S. Arora, "Optimization of drying process parameters for cauliflower drying," Journal of Food Science and Technology, vol. 50, pp. 62-69, 2013. Available at: https://doi.org/10.1007/s13197-011-0231-5.

[19] U. Garba and S. Kaur, "Effect of drying and pre-treatment on anthocyanins, flavonoids and ascorbic acid content of black carrot (Daucus carrota L.)," Journal of Global Biosciences, vol. 3, pp. 772- 777, 2014.

[20] M. Joshi, B. Adhikari, P. Aldred, J. Panozzo, and S. Kasapis, "Physicochemical and functional properties of lentil protein isolates prepared by different drying methods," Food Chemistry, vol. 129, pp. 1513-1522, 2011. Available at: https://doi.org/10.1016/j.foodchem.2011.05.131

[21] M. Wawire, I. Oey, F. Mathooko, C. Njoroge, D. Shitanda, and M. Hendrickx, "Thermal stability of ascorbic acid and ascorbic acid oxidase in African cowpea leaves (Vigna unguiculata) of different maturities," Journal of Agricultural and Food Chemistry, vol. 59, pp. 1774-1783, 2011. Available at: https://doi.org/10.1021/jf103469n.

[22] R. K. Toor and G. P. Savage, "Effect of semi-drying on the antioxidant components of tomatoes," Food Chemistry, vol. 94, pp. 90-97, 2006. Available at: https://doi.org/10.1016/j.foodchem.2004.10.054.

[23] L. Ruvini, D. WMMMK, J. Chathuni, V. Rizliya, W. Swarna, and C. Barana, "Effect of different drying methods on antioxidant activity of star fruits (Averrhoa carambola L.)," Journal of Nutrition and Diet Supplements, vol. 1, pp. 1-6, 2017.

[24] E. Demiray and Y. Tulek, "Color degradation kinetics of carrot (Daucus carota) slices during hot air drying," Journal of Food Processing and Preservation, vol. 39, pp. 1745-4549, 2013. 
[25] A. Shalata and P. M. Neumann, "Exogenous ascorbic acid (vitamin C) increases resistance to salt stress and reduces lipid peroxidation," Journal of Experimental Botany, vol. 52, pp. 2207-2211, 2001. Available at: https://doi.org/10.1093/jexbot/52.364.2207.

[26] M. S. Beltagi, "Exogenous ascorbic acid (vitamin C) induced anabolic changes for salt tolerance in chick pea (Cicer arietinum L.) plants," African Journal of Plant Science, vol. 2, pp. 118-123, 2008.

[27] T. S. Workneh and M. O. Oke, "Thin layer modelling of microwave-convective drying of tomato slices," International Journal of food Engineering, vol. 9, pp. 75-90, 2013. Available at: https://doi.org/10.1515/ijfe-2012-0205.

[28] I. Doymaz, N. Tugrul, and M. Pala, "Drying characteristics of dill and parsley leaves," Journal of Food Engineering, vol. 77, pp. 559565, 2006. Available at: https://doi.org/10.1016/j.jfoodeng.2005.06.070.

[29] P. J. Fellows, Food processing technology - principles and practice, 2nd ed. Cambridge, England, Boca Raton, Boston, New York, Washington, DC: CRC Press, Woodhead Publishing Limited, 2000.

[30] J. I. De-Corcuera, J. R. Cavalieri, and J. R. Powers, Blanching of foods. In D.R. Heldman (Ed.), Encyclopedia of Agricultural, Food, and Biological Engineering. New York: Marcel Dekker, Inc, 2004.

[31] A. Ali, Y. A. Yusof, N. Chin, and M. N. Ibrahim, "Effect of different drying treatments on colour, quality and ascorbic acid concentration of guava fruit," presented at the 2nd International Conference on Agricultural and Food Engineering, CAFE 2014, Kuala Lumpur, Malaysia, 2016. 